Reviu Akuntansi dan Bisnis Indonesia, Vol. 3 No. 1, Hlm: 67-84, Juli 2019

Website: http://journal.umy.ac.id/index.php/rab

\title{
Pengaruh Implementasi Syariah Governance Terhadap Kepuasan dan Loyalitas Muzakki (Studi pada Lembaga Amil Zakat Se-DIY)
}

\author{
Radita Dyah Puspitasari * Emile Satia Darma \\ Program Studi Akuntansi Universitas Muhammadiyah Yogyakarta
}

IN F O A R T I K E L

Kata Kunci:

Syariah Governance,

Satisfaction, Loyalty of

Muzakki, Amil Zakat

Institute.

Jenis Artikel:

Penelitian Empiris

*Correspondence:

radita.dyah@gmail.com

\begin{abstract}
A B S T R A K
The research aims to examine and obtain empirical study on the effect of syariah governance implementation toward satisfaction and loyalty of muzakki. The object of this research is Amil Zakat Institute in Daerah Istimewa Yogyakarta. Collecting data used purposive sampling method on muzakki who pay zakat through Amil Zakat Institute in Daerah Istimewa Yogyakarta. A total of 215 respondents used as samples in this study. The analysis tool used is structural equation model with AMOS 22.0. Testing the quality of the data used in this research is a confirmatory factor analysis and second order model, while the hypothesis testing used the structural model analysis. The results of the research showed that syariah governance has a positive significant effect on satisfaction and loyalty of muzakki, while satisfaction is not showing significant effect to the loyalty of muzakki.
\end{abstract}

(C) 2019 RAB. Published by Universitas Muhammadiyah Yogyakarta

\section{PENDAHULUAN}

Permasalahan ekonomi merupakan salah satu masalah yang sering dihadapi oleh berbagai negara, termasuk Indonesia. Indonesia mengalami krisis ekonomi pada tahun 1997 hal itu disebabkan karena sistem ekonomi di Indonesia tidak berjalan dengan semestinya. Selain itu, pemerintah juga tidak melaksanakan pembangunan ekonomi yang Islami, sehingga menyebabkan tingginya tingkat kemiskinan di Indonesia. Kemiskinan di Indonesia masih menjadi masalah yang penting karena masih belum maksimalnya peran pemerintah di dalam meningkatkan kesejahteraan masyarakat. Hal tersebut dibuktikan bahwa menurut berita CNNIndonesia, tingkat pertumbuhan ekonomi di Indonesia pada tahun 2017 baru mencapai 5,07\% yang masih berada di bawah target yaitu 7\%. Sedangkan utang Indonesia pada tahun 2017 telah mencapai Rp4.500 triliun. Dengan demikian, pemerintah perlu mencari solusi dan perlu membuat kebijakan untuk meningkatkan kesejahteraan masyarakat khususnya dalam hal penuntasan kemiskinan yang merupakan salah satu cara untuk meningkatkan perekonomian Indonesia.

Mengingat bahwa Indonesia merupakan negara muslim, yang mana 87\% masyarakat Indonesia memeluk agama Islam, maka salah satu ibadah wajib umat Islam yaitu zakat dapat dijadikan sebagai salah satu alternatif untuk mengurangi angka kemiskinan di Indonesia karena zakat dapat mengurangi kesenjangan sosial dan dapat membantu pemerintah untuk memelihara mustahiq sesuai dengan amanat UUD 1945 agar kehidupan mereka dapat terus berlangsung dan terjamin. Potensi zakat di Indonesia cukup besar namun realisasi pengumpulan zakatnya masih berada jauh di bawah dari potensi yang ada. Menurut data penelitian BAZNAS, potensi zakat di Indonesia setiap tahunnya mengalami peningkatan. Pada tahun 2010 potensi pengumpulan zakat mencapai Rp217 triliun dan terus mengalami peningkatan hingga tahun 2016 yang mana potensi 
zakat mencapai Rp286 triliun. Angka tersebut menunjukkan adanya peningkatan potensi pengumpulan zakat di Indonesia, namun zakat nasional yang dikumpulkan oleh Lembaga Amil Zakat baru mencapai Rp5,1 triliun atau sekitar 1\% dari potensi yang ada. Hal tersebut membuktikan bahwa pengumpulan zakat nasional pada Lembaga Amil Zakat masih relatif rendah (republika.co.id).

Daerah Istimewa Yogyakarta merupakan salah satu daerah yang memiliki potensi pengumpulan zakat yang cukup tinggi, selain itu Daerah Istimewa Yogyakarta juga tercatat sebagai daerah yang mayoritas masyarakatnya beragama Islam. Menurut data Badan Pusat Statistika, pada tahun 2010 ada sekitar 92\% atau 3.179.129 jiwa masyarakat DIY memeluk agama Islam. Sedangkan jumlah penduduk miskin di Daerah Istimewa Yogyakarta pada tahun 2017 masih mencapai 466,33 ribu orang (yogyakarta.bps.go.id).

BAZNAS DIY menyebutkan potensi pengumpulan zakat, infaq, dan sedekah oleh BAZNAS DIY pada tahun 2016 telah mencapai Rp4,38 miliar, hal ini akan mengurangi angka kemiskinan di DIY apabila potensi zakat tersebut dapat dimaksimalkan. Penghimpunan zakat di DIY mengalami peningkatan pada tahun 2017 yaitu sebesar Rp2 miliar dan pada tahun 2018 sebesar Rp8,1 miliar, namun menurut Kepala Kantor Kementrian Agama Wilayah Yogyakarta, Muhammad Lutfi Hamid, walaupun penghimpunan zakat di DIY mengalami peningkatan tetapi zakat yang dihimpun oleh BAZNAS DIY masih di bawah $10 \%$ dari potensi yang ada. Hal ini dibuktikan bahwa wilayah DIY memiliki potensi zakat sebesar Rp15 miliar namun realisasi penghimpunan zakat di DIY pada tahun 2016 baru mencapai sekitar Rp900 juta, hal tersebut menunjukkan bahwa penghimpunan zakat di DIY baru mencapai 6\% (harianjogja.com).

Rendahnya realisasi penghimpunan zakat di DIY dari potensi zakat yang ada dikarenakan pengelolaan zakat di Daerah Istimewa Yogyakarta masih belum optimal, sehingga perlu adanya suatu lembaga yang mampu mengelola dana zakat secara profesional. Lembaga Amil Zakat merupakan suatu lembaga yang dibentuk oleh masyarakat, yang bertugas untuk menghimpun, mengelola, dan menyalurkan zakat dengan baik dan tepat serta sesuai dengan syariat Islam. Lembaga Amil Zakat (LAZ) adalah lembaga pengelolaan zakat yang dibentuk atas prakarsa masyarakat yang bergerak di bidang dakwah, pendidikan, dan sosial, yang ditujukan untuk kemaslahatan umat Islam. Lembaga Amil Zakat dikukuhkan, dibina, dan dilindungi oleh pemerintah, sehingga dalam melaksanakan tugasnya, LAZ bertanggung jawab dan harus melaporakan seluruh kegiatannya kepada pemerintah. Namun kepercayaan masyarakat terhadap LAZ masih rendah, karena masih banyak masyarakat yang memilih untuk menyalurkan zakatnya melalui lembaga penghimpun zakat yang belum memiliki izin secara resmi untuk mengelola zakat. Hal tersebut dikarenakan lembaga amil zakat hanya berfokus pada bagaimana meningkatkan penghimpunan zakat tanpa memperhatikan bagaimana kualitas pelayanan dan keamanan dalam pengelolaan serta penyaluran dana ZIS. (antaranews.com). Dengan demikian dibutuhkan adanya suatu tata kelola yang baik yang diwujudkan dalam pertanggungjawaban yang diberikan oleh LAZ kepada muzakki sehingga akan meningkatkan reputasi dan kepercayaan masyarakat terhadap LAZ serta dapat meningkatkan penghimpunan zakat di Indonesia.

Pertanggungjawaban dan pemberian pelayanan yang baik, diwujudkan oleh LAZ dalam implementasi syariah governance. Syariah Governance merupakan pengembangan konsep prinsipprinsip good corporate governance. Terdapat enam prinsip pada aturan syariah governance dengan menambahkan syariah compliance pada prinsip tersebut (Junusi, 2013). Syariah governance diharapkan mampu meningkatkan reputasi serta kepercayaan masyarakat terhadap lembaga keuangan syariah. Prinsip syariah governance terdiri dari akuntabilitas, responsibilitas, transparansi, independensi, keadilan, dan syariah compliance (Purnamasari dan Darma, 2015).

Syariah governance merupakan hal fundamental bagi seluruh lembaga keuangan syariah yang tidak kalah penting daripada corporate governance pada setiap institusi. Peran syariah governance adalah untuk memastikan kepercayaan stakeholders terhadap lembaga keuangan syariah. Selain itu, dengan meningkatkan prinsip syariah governance, maka akan dapat membantu meningkatkan pertumbuhan lembaga keuangan syariah. Implementasi syariah governance dapat mendorong LAZ untuk selalu memberikan pelayanan yang baik, amanah, jujur, adil, dan sesuai dengan syariah serta mampu memenuhi harapan dan kebutuhan dari muzakki. Dengan demikian penerapan prinsip 
syariah governance diharapkan dapat memberikan kepuasan bagi para muzakki dan dapat menciptakan suatu loyalitas muzakki sehingga dapat meningkatkan penghimpunan zakat di Indonesia khususnya di DIY, serta dapat membantu pemerintah untuk mengurangi angka kemiskinan di Indonesia.

Penelitian yang mengaitkan hubungan antara syariah governance, kepuasan, dan loyalitas muzakki khususnya pada Lembaga Amil Zakat masih jarang dilakukan. Oleh karenanya, penting untuk dilakukan penelitian untuk menjawab rumusan masalah apakah syariah governance berpengaruh positif dan signifikan terhadap kepuasan dan loyalitas muzakki serta apakah kepuasan berpengaruh positif dan signifikan terhadap loyalitas muzakki. Hasil penelitan ini diharapkan dapat memberikan implikasi dalam ranah praktik, dan kontribusi khususnya dalam pengembangan konsep syariah governance.

\section{TINJAUAN LITERATUR DAN PERUMUSAN HIPOTESIS}

\section{Teori Legitimasi}

Teori legitimasi berfokus pada hubungan interaksi antara perusahaan atau entitas dengan masyarakat. Teori ini menyebutkan bahwa perusahaan merupakan bagian dari masyarakat sehingga perusahaan harus memperhatikan dan menyesuaikan diri dengan norma sosial yang berlaku di masyarakat. Perusahaan berusaha menyesuaikan diri dengan keadaan dan peraturan yang berlaku sehingga dapat diterima oleh masyarakat dan mereka merasa bahwa organisasi tersebut beroperasi berdasarkan nilai-nilai yang di dalam masyarakat. Legitimasi masyarakat merupakan hal penting bagi suatu perusahaan untuk menentukan arah perkembangan perusahaan di masa yang akan datang. Hal itu dapat dijadikan sebagai dasar untuk menentukan rencana strategis perusahaan, terutama yang terkait dengan upaya menyesuaikan diri dengan kondisi lingkungan yang semakin berkembang pesat. Legitimasi organisasi merupakan sesuatu hal yang diinginkan oleh perusahaan dari masyarakat. Dengan demikian, legitimasi merupakan sumber daya potensial bagi perusahaan untuk mempertahankan kelangsungan hidupnya (going concern). Teori legitimasi dalam penelitian ini mengimplikasikan prinsip-prinsip syariah governance yang dilakukan oleh Lembaga Amil Zakat merupakan cara untuk mendapatkan pengakuan (legitimasi) dari muzakki.

Teori Stakeholder

Teori stakeholder menyebutkan bahwa perusahaan bukan suatu entitas yang beroperasi untuk hanya kepentingannya sendiri, melainkan perusahaan juga harus memberikan manfaat bagi stakeholder. Dengan demikian, keberadaan suatu perusahaan sangat dipengaruhi oleh dukungan yang diberikan stakeholder kepada perusahaan tersebut (Chariri dan Ghozali, 2007). Deegan (2004) menjelaskan bahwa teori stakeholder merupakan suatu teori yang menyatakan bahwa seluruh stakeholder memiliki hak yang sama untuk memperoleh suatu informasi yang berkaitan dengan seluruh kegiatan/aktivitas perusahaan yang dapat memengaruhi pengambilan keputusannya. Lembaga Amil Zakat merupakan lembaga yang bergerak di bidang sosial sehingga LAZ tidak bertujuan untuk mencari laba melainkan untuk menciptakan kesejahteraan umat. Teori stakeholder menyatakan stakeholder sebagai pengambil keputusan muslim mengharapkan Lembaga Amil Zakat mengungkapkan pertanggungjawabannya untuk memenuhi konsep syariah governance yang sesuai dengan syariah Islam, sehingga dapat membuktikan bahwa Lembaga Amil Zakat beroperasi sesuai dengan prinsip kepatuhan syariah. Hasil implikasi dari pertanggungjawaban Lembaga Amil Zakat diharapkan dapat memudahkan muzakki untuk mengambil segala keputusan yang berkaitan dengan pembayaran dana zakat, infak, dan sedekah (ZIS) melalui lembaga tersebut. 


\section{Teori Persepsi}

Definisi persepsi menurut Kamus Besar Bahasa Indonesia (KBBI) adalah suatu tanggapan dari suatu proses atau serapan yang perlu diketahui oleh seseorang dengan menggunakan panca inderanya. Persepsi tiap individu akan berbeda dengan persepsi individu lainnya. Perbedaaan persepsi dapat berupa pengalaman, pengetahuan, sudut pandang, dan cara berpikir untuk menganalisis sesuatu hal (Aviyatisari, 2016). Sugihartono, dkk (2007) menyatakan bahwa persepsi adalah kemampuan otak untuk menerjemahkan atau memproses stimulus yang masuk ke dalam alat indera manusia. Persepsi setiap individu berbeda tergantung sudut pandangnya. Persepsi positif atau negatif akan mempengaruhi tindakan manusia. Walgito (2004) mengatakan bahwa persepsi adalah proses pengorganisasian dan penginterpretasian terhadap stimulus yang diterima oleh setiap individu sehingga menjadi sesuatu yang berarti bagi individu tersebut. Respon dari setiap individu tergantung pada perhatian individu yang bersangkutan. Setiap individu memiliki perasaan, kemampuan berfikir, dan pengalaman-pengalaman yang berbeda, sehingga hasil persepsi mungkin akan berbeda antar individu satu dengan individu lain. Berdasarkan beberapa penjelasan makna persepsi di atas, maka dapat disimpulkan bahwa persepsi merupakan proses seseorang dalam memberikan tanggapan dengan menggunakan seluruh panca inderanya, berdasarkan serapan, cara pandang, dan pola pikir yang dilakukan subyek terhadap obyek yang diteliti, yang kemudian akan diintrepretasikan.

Implementasi prinsip syariah governance akan mempengaruhi persepsi dari masing-masing muzakki. Setiap pelayanan yang diberikan oleh LAZ juga akan mempengaruhi pola pikir dan cara pandang muzakki terhadap lembaga tersebut dan akan mempengaruhi pengambilan keputusan dari muzakki dalam menyalurkan zakatnya melalui Lembaga Amil Zakat. Apabila muzakki memiliki persepsi yang positif terhadap LAZ karena mereka menganggap bahwa LAZ telah memberikan pelayanan yang baik, maka muzakki akan cenderung percaya dan yakin untuk menyalurkan zakatnya melalui lembaga tersebut.

Teori Stewardship

Teori stewardship didasarkan atas kepentingan bersama, sehingga tindakan yang dilakukan oleh manajer akan mengacu pada kepentingan bersama yaitu untuk mencapai tujuan organisasi. Jika terdapat perbedaan kepentingan antara organisasi dengan manajer, maka akan adanya kerjasama antara manajer dengan organisasi sehingga tujuan bersama akan tercapai. Sifat amanah, memiliki integritas, bertindak jujur dan bertanggungjawab dijadikan dasar untuk membangun teori stewardship di dalam penelitian ini. Dalam pandangan teori stewardship, manajemen dapat dipercaya apabila manajer bekerja dengan baik untuk kepentingan publik (Kaihatu, 2006). Penelitian ini menggunakan teori stewardship karena teori ini memandang bahwa kepercayaan atas lembaga amil zakat didasarkan atas tindakannya yang sesuai dengan kepentingan publik. Teori juga ini menjelaskan bahwa meningkatnya kinerja perusahaan disebabkan karena adanya sifat amanah dan kesetiaan dari manajer perusahaan terhadap komitmen perusahaan.

\section{Syariah Governance}

Menurut Undang-undang Zakat No. 23 Tahun 2011, pengelolaan dana zakat, infaq, dan sedekah (ZIS) harus sesuai dengan syariat Islam dan memperhatikan faktor-faktor seperti amanah, keadilan, kemanfaatan, terintegrasi, kepastian hukum, dan akuntabilitas. Dari keenam asas tersebut sesuai dengan 5 prinsip good corporate governance yang terdiri akuntabilitas, responsibility, transparency, independent, dan keadilan. Kelima prinsip pokok GCG tersebut sesuai dengan nilai dan norma Islam yang ada di dalam kehidupan seorang muslim.

Seiring berkembangnya pengetahuan syariah di kalangan masyarakat, maka semakin banyak pengaplikasian prinsip syariah yang diterapkan di dalam kehidupan masyarakat. Seperti lingkup pembayaran zakat yang memiliki perkembangan dengan mendirikan lembaga amil zakat maupun organisasi pengelolaaan zakat serta lembaga keuangan yang berkaitan dengan syariah. Dengan 
demikian dapat kita lihat bahwa penerapan good corporate governance yang telah diatur dalam undang-undang, saat ini mengembangkan syariah governance yang diterapkan pada lembaga/organisasi berbasis syariah. Prinsip syariah governance pertama kali dikenalkan oleh Junusi (2013), yang disebutkan bahwa implementasi syariah governance merupakan replikasi dari prinsip-prinsip good corporate governance dengan menambahkan satu prinsip yaitu kepatuhan syariah. Penelitian tersebut kemudian dikembangkan oleh Purnamasari dan Darma (2015), yang mana prinsip kepatuhan syariah merupakan salah satu prinsip penting untuk meningkatkan kepercayaan masyarakat terhadap lembaga keuangan syariah sehingga dapat mempengaruhi keberlangsungan hidup lembaga keuangan syariah tersebut.

Adanya prinsip transparansi akan secara tidak langsung mendorong pengungkapan informasi yang sebenarnya atau sesungguhnya baik kinerja maupun keuangan sehingga seluruh stakeholders dapat mengukur dan mengantisipasi segala aktivitas yang dilakukan LAZ. Akuntanbilitas yaitu kejelasan fungsi dan pelaksanaan pertanggungjawaban organisasi sehingga pengelolaannya dapat berjalan secara efektif (Purnamasari dan Darma, 2015). Pertanggungjawaban merupakan pengelolaan yang dilakukan dalam keseuaian suatu perusahaan terhadap peraturan perundangundangan yang berlaku (Arbaina, 2012). Kemandirian yaitu memiliki kompetensi, mampu bertindak obyektif, dan bebas dari pengaruh atau tekanan dari pihak manapun (independen) serta memiliki komitmen yang tinggi untuk mengembangkan LAZ. Keadilan (fairness) yaitu kesetaraan dalam memenuhi hak-hak stakeholders berdasarkan perjanjian dan peraturan perundang-undangan yang berlaku (Purnamasari dan Darma, 2015). Penerapan syariah compliance memiliki tujuan untuk menghindari dari transaksi maysir, gharar, riba, dan transaksi-transaksi lainnya yang tidak sesuai dengan kaidah pada praktik syariah.

Kepuasan

Salah satu faktor penting bagi keberhasilan lembaga/ badan amil zakat dalam memberikan kepuasan kepada muzakki adalah kualitas layanan yang diberikan kepada muzakki. Kepuasan menjadi salah satu unsur penting dalam penyediaan layanan yang baik, efisien, dan efektif. Apabila muzakki merasa tidak puas dengan pelayanan yang diberikan maka dapat dipastikan pelayanan tersebut tidak efisien dan efektif. Ketercapaian kepuasan muzakki terjadi apabila pemenuhan pelayanan kepada muzakki terpenuhi. Kepuasan muzakki merupakan respon yang diberikan muzakki terhadap lembaga amil zakat atas kesesuaian kepentingan dan kinerja aktual dari lembaga tersebut.

Loyalitas

Menurut Wantara (2015) loyalitas merupakan sikap atau perilaku seorang konsumen yang menguntungkan perusahaan, seperti melakukan pembelian ulang terhadap produk atau jasa perusahaan dan merekomendasikan produk dan jasa tersebut kepada orang lain. Loyalitas dapat diukur dengan kesetiaan muzakki yang dicirikan dengan muzakki yang melakukan pembayaran zakat pada lembaga amil zakat atau organisasi pengelolaan zakat resmi secara terus-menerus, sehingga lembaga amil zakat perlu membuat rencana strategis agar mendapatkan citra yang baik dari sisi pelayanan maupun pengelolaan zakat.

Gunawan (2017) menyebutkan bahwa loyalitas bisa menyebabkan keterikatan muzakki dengan lembaga zakat terutama pada program-program yang akan diterapkan. Selain itu dengan adanya loyalitas muzakki, maka muzakki tersebut akan datang dan membayarkan zakat secara rutin dan juga akan menceritakannya serta mengajak orang lain untuk membayarkan zakatnya pada lembaga amil zakat tersebut. Apabila orang-orang yang ada di dalam lembaga zakat bisa memberikan layanan yang baik serta mampu menciptakan suatu loyalitas bagi muzakki maka hal tersebut akan meningkatkan pengumpulan hasil zakat. Kemajuan lembaga tersebut akan berujung pada kemakmuran masyarakat pada umumnya khususnya bagi umat muslim. 
Hubungan antara Syariah Governance dengan Kepuasan

Lembaga Amil Zakat bergerak di bidang kemanusiaan dan sosial, sehingga LAZ selalu berupaya untuk mengutamakan kepentingan umat. Untuk memenuhi kepentingan umat, LAZ menjalankan kegiatannya dengan jujur, amanah, tanggungjawab, dan sesuai dengan prinsip syariah. Hal tersebut sesuai dengan prinsip-prinsip syariah governance dan didukung oleh teori Stewardship, yang mana di dalam teori tersebut disebutkan bahwa manajemen dapat dipercaya apabila manajemen bekerja dengan baik untuk kepentingan publik (Kaihatu, 2006).

Syariah governance merupakan salah satu prinsip yang membedakan antara lembaga keuangan syariah dengan konvensional. Salah satu prinsip syariah governance yang paling membedakan dengan lembaga keuangan konvensional adalah syariah compliance (kepatuhan terhadap prinsip syariah). Di dalam beberapa penelitian di sejumlah lembaga keuangan syariah, penerapan Good Corporate Governance terbukti mampu meningkatkan reputasi lembaga keuangan syariah dan meningkatkan kepuasan serta kepercayaan masyarakat terhadap lembaga tersebut.

Menurut penelitian BAZNAS dan FEM IPB (2011), salah satu faktor yang menyebabkan seseorang membayar zakat di Lembaga Amil Zakat adalah karena adanya faktor kepuasan atas kinerja lembaga amil zakat. Kinerja Lembaga Amil Zakat dapat dilihat melalui implementasi syariah governance yang dijalankan oleh lembaga tersebut. Apabila Lembaga Amil Zakat menerapkan prinsip ini maka lembaga tersebut akan memberikan pelayanan yang baik dan juga sesuai dengan prinsip-prinsip syariah, sehingga nantinya akan memberikan kepuasan bagi muzakki. Apabila LAZ menerapkan prinsip-prinsip syariah governance di dalam setiap kegiatannya, maka LAZ akan berupaya untuk memberikan pelayanan yang terbaik dan sesuai dengan syariat Islam, dengan demikian LAZ akan memperoleh kepercayaan dari muzakki. Timbulnya rasa percaya muzakki terhadap Lembaga Amil Zakat, disebabkan karena adanya rasa puas dan yakin atas layanan yang diberikan oleh lembaga tersebut. Ketercapaian kepuasan muzakki terjadi apabila pemenuhan pelayanan sesuai dengan harapan muzakki. Kepuasan muzakki merupakan respon yang diberikan muzakki terhadap Lembaga Amil Zakat atas kesesuaian kepentingan dan kinerja aktual dari lembaga tersebut. Kepuasan juga dapat tercipta apabila muzakki memiliki persepsi positif terhadap LAZ. Dengan demikian semakin tinggi implementasi syariah governance di dalam Lembaga Amil Zakat, maka akan semakin tinggi tingkat kepuasan yang didapatkan oleh muzakki.

Sejalan dengan penelitian Firmansyah dan Devi (2017), disebutkan bahwa untuk meningkatkan potensi zakat di Indonesia maka diperlukan adanya prinsip-prinsip good shariah governance pada Lembaga Amil Zakat untuk meningkatkan kepuasan dalam pembayaran zakat. Penelitian Jumaizi (2011) juga menyatakan bahwa transparansi informasi berpengaruh positif dan signifikan terhadap kepuasan muzakki dalam menunaikan zakat pada Lembaga Amil Zakat. Dari penjabaran di atas maka hipotesis yang diajukan adalah:

\section{$\boldsymbol{H}_{\boldsymbol{1}} \quad$ : Syariah governance berpengaruh positif dan signifikan terhadap kepuasan muzakki.}

\section{Hubungan antara Syariah Governance dengan Loyalitas Muzakki}

Lembaga Amil Zakat merupakan suatu lembaga yang beroperasi untuk memberikan manfaat bagi seluruh umat manusia khususnya umat muslim. Dalam rangka memberikan kemanfaatan untuk kepentingan umat, LAZ berupaya untuk memberikan jasa layanan di bidang kemanusiaan dan sosial seperti penghimpunan, pengelolaan, dan penyaluran dana ZIS. LAZ menjaga kepercayaan masyarakat dan memenuhi kepentingan umat dengan menerapkan prinsip syariah governance di dalam setiap kegiatannya. Dengan demikian, LAZ menjalankan seluruh kegiatannya dengan jujur, amanah, adil, terbuka, sesuai dengan syariah, dan selalu memberikan informasi mengenai seluruh kegiatan lembaga zakat yang dapat mempengaruhi pengambilan keputusan bagi para muzakki. Dengan menerapkan prinsip syariah governance dan memberikan layanan yang baik serta terpercaya, maka masyarakat dapat menilai bahwa lembaga zakat tersebut dapat menghimpun, 
mengelola, dan menyalurkan dana ZIS dengan baik dan tepat sasaran sehingga akan mempengaruhi keputusan muzakki untuk menyalurkan dana ZIS melalui lembaga tersebut. Hal itu didukung oleh teori stakeholder yang menyatakan bahwa stakeholder sebagai pengambil keputusan muslim mengharapkan Lembaga Amil Zakat mengungkapkan pertanggungjawabannya untuk memenuhi konsep syariah governance yang sesuai dengan syariah Islam, sehingga dapat membuktikan bahwa Lembaga Amil Zakat beroperasi sesuai dengan prinsip kepatuhan syariah. Hasil implikasi dari pertanggungjawaban Lembaga Amil Zakat diharapkan dapat memudahkan muzakki untuk mengambil segala keputusan yang berkaitan dengan pembayaran dana zakat, infak, dan sedekah (ZIS) melalui Lembaga Amil Zakat.

Apabila LAZ terus memberikan pelayanan yang baik dengan menerapkan prinsip syariah governance, maka akan mempengaruhi keputusan muzakki dalam membayarkan zakatnya, dan apabila hal tersebut terjadi dalam jangka waktu yang panjang maka akan menyebabkan suatu loyalitas muzakki, serta akan meningkatkan perolehan penghimpunan dana zakat. Lembaga Amil Zakat yang amanah, bertanggungjawab dan memiliki kredibilitas, juga dapat memengaruhi cara pandang dan pola pikir muzakki terhadap lembaga tersebut. Jika LAZ terus memberikan pelayanan yang baik maka LAZ akan memiliki citra yang baik dan muzakki akan memiliki persepsi yang baik terhadap LAZ sehingga akan mempengaruhi keputusan muzakki dalam pembayaran zakat untuk jangka panjang, dengan demikian akan terciptanya suatu loyalitas dalam menyalurkan zakatnya melalui Lembaga Amil Zakat (Sutomo dkk, 2017). Hal ini didukung oleh teori persepsi, yang mana suatu tindakan atau kejadian dapat mempengaruhi persepsi seseorang. Persepsi diartikan sebagai suatu proses berupa tanggapan yang diberikan oleh seseorang berdasarkan cara pandang dan pola pikirnya terhadap suatu kejadian tersebut. Loyalitas merupakan tanggapan dari muzakki, yang mana muzakki telah memiliki sudut pandang dan pola pikir tersendiri atas kualitas layanan dan citra dari Lembaga Amil Zakat tersebut.

Hal ini juga didukung oleh penelitian yang dilakukan Umam (2011) yang menyatakan bahwa good corporate governance berpengaruh signifikan terhadap loyalitas nasabah. Namun penelitian tersebut berlawanan dengan penelitian yang dilakukan oleh Purnamasari dan Darma (2015), yang mana di dalam penelitian tersebut disebutkan bahwa variabel keadilan dan syariah compliance berpengaruh positif dan signifikan terhadap loyalitas nasabah, sedangkan variabel transparansi, akuntabilitas, responsibilitas, dan kemandirian tidak berpengaruh secara signifikan terhadap loyalitas nasabah. Berdasarkan penelitian Choiriyyah (2016), disebutkan bahwa prinsip transparansi dan syariah compliance berpengaruh positif dan signifikan terhadap loyalitas muzakki. Namun Choiriyyah (2016) menyebutkan bahwa prinsip keadilan, akuntabilitas, resposibilitas, dan kemandirian tidak berpengaruh positif dan signifikan terhadap loyalitas muzakki. Penelitian tersebut sejalan dengan penelitian Mahardika (2018) yang menyebutkan bahwa akuntabilitas tidak berpengaruh positif dan signifikan terhadap minat muzakki dalam menyalurkan dana zakat, namun di dalam penelitian Mahardika (2018) disebutkan bahwa responsibilitas, keadilan, independensi, dan transparansi berpengaruh positif dan signifikan terhadap minat muzakki dalam menyalurkan dana zakat. Hal tersebut juga berlawanan dengan penelitian Jumaizi,dkk (2011) yang menyebutkan bahwa prinsip-prinsip good corporate governance mempunyai pengaruh yang positif dan signifikan terhadap kepuasan serta loyalitas muzakki. Hal tersebut sejalan dengan penelitian Assaggaf (2016) yang menyebutkan bahwa transparansi dan akuntabilitias berpengaruh positif dan signifikan terhadap kepuasan serta loyalitas muzakki. Dengan demikian karena adanya ketidak-konsistenan dari hasil penelitian terdahulu, maka peneliti ingin meneliti kembali pengaruh syariah governance terhadap loyalitas muzakki. Dari penjabaran diatas maka hipotesis yang diajukan adalah:

\section{$\boldsymbol{H}_{2} \quad$ :Syariah governance berpengaruh positif dan signifikan terhadap loyalitas muzakki.}

Hubungan antara Kepuasan dengan Loyalitas Muzakki

Pertanggungjawaban Lembaga Amil Zakat diwujudkan dalam kualitas layanan yang diberikannya. Kualitas layanan yang diberikan oleh LAZ akan mempengaruhi persepsi, pandangan 
muzakki terhadap lembaga tersebut, serta keputusan untuk menyalurkan dana ZIS. Selain itu kualitas layanan yang baik akan memberikan suatu kepuasan bagi muzakki, karena hasil yang didapatkan oleh muzakki dari lembaga amil tersebut sesuai dengan harapan dan kebutuhannya. LAZ diharapkan dapat memberikan pelayanan yang berkualitas agar muzakki mendapatkan kepuasan sehingga meningkatkan loyalitasnya dalam menyalurkan dana zakat.

Kepuasan dapat dilihat dari berbagai macam persepsi masing-masing individu. Hal ini didukung oleh teori persepsi, yang mana suatu tindakan atau kejadian dapat mempengaruhi persepsi seseorang dan masing-masing individu memiliki persepsi yang berbeda. Apabila muzakki merasa puas terhadap LAZ, maka muzakki akan cenderung membayarkan zakatnya secara berulang melalui lembaga dan bila hal tersebut dirasa benar-benar dapat diyakini untuk dilakukan dalam waktu yang lama maka akan timbul loyalitas terhadap lembaga tersebut. Kepuasan merupakan salah satu hal penting bagi perusahaan/organisasi jasa, karena pelanggan tersebut akan menyebarluaskan perasaan puasnya kepada calon pelanggan lainya. Dengan demikian, kepuasan pelanggan akan meningkatkan loyalitas terhadap perusahaan. Untuk meningkatkan keuntungan perusahaan, kepuasan dan loyalitas pelanggan menjadi faktor penting bagi perusahaan, sehingga perusahaan selalu menjaga hubungan baik dengan pelanggan. Menurut Ishak dan Luthfi, (2011), loyalitas pelanggan terbentuk dari kepuasan pelanggan jangka panjang. Kepuasan muzakki juga merupakan salah satu hal yang penting bagi lembaga amil zakat. Ketika muzakki merasa puas terhadap pelayanan yang diberikan oleh Lembaga Amil Zakat maka muzakki akan cenderung untuk kembali membayarkan zakatnya pada lembaga amil zakat tersebut, yang mana hal ini adalah indikator yang menyebabkan timbulnya loyalitas muzakki.

Wantara (2015) menyebutkan bahwa kepuasan memiliki pengaruh yang positif dan signifikan terhadap loyalitas. Kepuasan muzakki ini sangat penting bagi setiap lembaga amil zakat untuk menciptakan loyalitas muzakki itu sendiri. Terdapat beberapa faktor yang dapat memengaruhi kepuasan muzakki di antaranya yaitu kualitas jasa dan pelayanan yang baik dan kemudahan yang diberikan oleh LAZ. Hal ini sejalan dengan penelitian Yuliafitri dan Khoiriyah (2016) yang juga membuktikan adanya pengaruh yang positif dan signifikan antara kepuasan dengan loyalitas muzakki. Semakin tinggi tingkat kepuasan muzakki maka akan semakin tinggi pula tingkat loyalitasnya. Hasil serupa juga ditemukan dalam penelitian Gunawan (2017), Hayati (2017), Windriatmoko (2016), dan Adnan (2018). Dari penjabaran diatas maka hipotesis yang diajukan adalah:

\section{$\boldsymbol{H}_{s} \quad$ : Kepuasan muzakki berpengaruh positif dan signifikan terhadap loyalitas muzakki}

\section{METODE PENELITIAN}

Jenis Penelitian, Jenis dan Sumber Data, Objek Penelitian

Penelitian ini merupakan jenis penelitian lapangan dengan menggunakan pendekatan kuantitatif. Data primer dalam penelitian ini adalah data yang didapatkan secara langsung dari penyebaran kuesioner kepada muzakki sebagai objek penelitian yang terpilih. Adapun objek penelitian yang digunakan adalah Lembaga Amil Zakat di Daerah Istimewa Yogyakarta, dengan menggunakan sampel muzakki yang menyalurkan zakatnya melalui Lembaga Amil Zakat di DIY. Teknik Pengambilan Sampel

Sampel pada penelitian ini adalah muzakki yang menyalurkan zakatnya melalui Lembaga Amil Zakat di DIY yang pada saat penelitian ini dilakukan masih menjadi wajib zakat di Lembaga Amil Zakat yang telah memiliki izin resmi (memiliki SK).

Model Penelitian

Model penelitian penelitian ini disajikan pada Gambar 1. Berdasarkan pada tinjauan pustaka maka kerangka pemikiran teoritis yang disajikan dalam penelitian ini adalah sebagai berikut: 


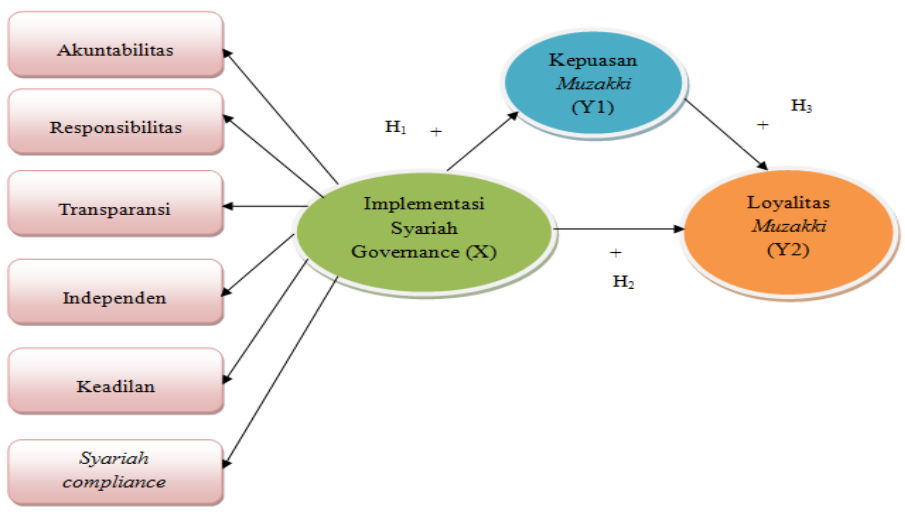

Gambar 1 Model Penelitian

Definisi Operasional Variabel Penelitian

Definisi operasional adalah penjabaran dari masing-masing variabel terhadap indikator yang membentuknya. Indikator-indikator variabel pada penelitian ini adalah sebagai berikut:

Akuntabilitas

Akuntabilitas merupakan terjemahan kata berbahasa Inggris yaitu accountability, yang memiliki arti kemampuan untuk mempertanggungjawabkan dan menjelaskan apa segala kegiatan yang telah dilakukan. Adapun indikator yang digunakan untuk mengukur akuntabilitas adalah kejelasan fungsi, pelaksanaan, penilaian kinerja untuk pengambilan keputusan, dan penilaian pertanggungjawaban dengan skala likert 5 poin (Wardayati, 2011).

Responsibilitas

Responsibilitas merupakan upaya untuk mengelola perusahaan dengan memperhatikan peraturan perundang-undangan yang berlaku dan prinsip-prinsip pengelolaan lembaga keuangan yang sehat. Menurut Wardayati (2011) indikator yang digunakan untuk mengukur responsibilitas adalah taat pada peraturan dan peduli dengan lingkungan serta masyarakat. Pengukuran dilakukan dengan menggunakan skala likert 5 poin.

Transparansi

Transparansi adalah sikap keterbukaan dalam mengemukakan informasi yang material dan relevan dan juga merupakan sikap keterbukaan dalam proses pengambilan keputusan. Adapun indikator yang digunakan untuk mengukur transparansi adalah keterbukaan, kemudahakn mendapat informasi, dan informasi yang relevan dengan skala likert 5 poin (Wardayati, 2011).

Independensi

Independensi yaitu kemampuan bertindak obyektif serta bebas dari tekanan dan pengaruh pihak lain (independen). Selain itu lembaga keuangan yang mandiri berarti memiliki komitmen yang tinggi terhadap perusahaannya. Adapun indikator yang digunakan untuk mengukur independensi adalah pengelolaan yang profesional dan tanggungjawab serta independen tanpa campur tangan siapapun dengan skala likert 5 poin (Junusi, 2013). 
Keadilan

Keadilan merupakan wujud kesetaraan dalam pemenuhan hak-hak stakeholders berdasarkan perjanjian dan peraturan perundang-undangan yang berlaku. Adapun indikator untuk mengukur keadilan yaitu keadilan dan kesetaraan dengan skala likert 5 poin (Junusi, 2013).

Syariah Compliance

Syariah compliance dijadikan sebagai indikator untuk mengukur kepatuhan peraturan pada prinsip-prinsip syariah. Penerapan prinsip ini bertujuan untuk menghindari transksi yang mengandung unsur maysir, gharar, dan riba. Wardayati (2011) melakukan penelitian yang menyebutkan bahwa syariah compliance merupakan indikator berpengaruh dalam implementasi syariah governance. Adapun indikator untuk mengukur syariah compliance adalah bebas dari riba dan gharar, bisnis yang halal, serta pengelolaan usaha yang amanah dengan skala likert 5 poin (Junusi, 2013).

Kepuasan

Kepuasan adalah perasaan puas akan produk atau jasa yang ditawarkan yang sesuai dengan kriteria yang diinginkan. Penelitian Yuliafitri dan Khoiriyah (2016) menggunakan beberapa indikator untuk mengukur tingkat kepuasan yaitu kemudahan dalam memperoleh jasa, kualitas layanan, dan pemenuhan kebutuhan muzakki. Kepuasan diukur menggunakan skala likert 5 poin.

Loyalitas Muzakki

Loyalitas muzakki merupakan sikap yang ditunjukkan oleh seorang wajib zakat dengan kesetiaan untuk membayarkan zakat di lembaga amil zakat yang berlangsung secara terus-menerus. Menurut Umam (2011) ada 3 indikator yang digunakan untuk mengukur loyalitas yaitu repeat, referral, dan retention. Loyalitas diukur menggunakan skala likert 5 poin.

Metode Pengolahan dan Analisis Data

Pembahasan hasil penelitian ini terdiri dari suji confirmatory factor analysis (CFA), uji model struktural, pengujian asumsi klasik (uji normalitas, uji outlier, dan multikolinearitas), dan uji hipotesis. Uji hipotesis dengan menggunakan Structure Equation Model (SEM) dilakukan dalam rangka menguji apakah hipotesis diterima atau tidak. Hipotesis diterima apabila nilai probabilitas $<0,05$ (Ghozali, 2014).

\section{HASIL DAN PEMBAHASAN}

Hasil Uji Kualitas Instrumen

Statistik Deskriptif

Penelitian ini merupakan penelitian survey yaitu dengan menyebarkan kuesioner kepada responden. Responden penelitian adalah muzakki yang menyalurkan zakatnya melalui Lembaga Amil Zakat di DIY. Kuesioner yang disebarkan sebanyak 250 buah. Kuesioner diberikan kepada muzakki yang aktif menyalurkan zakat melalui LAZ, dari 250 kuesioner yang dapat diolah sebanyak 215 kuesioner, sisanya 15 kuesioner tidak dapat diolah dikarenakan kuesioner tidak kembali kepada peneliti dan 20 kuesioner tidak memenuhi kriteria (responden rate 86\%). 
Deskriptif data penelitian dapat dilihat dari jawaban deskriptif responden setelah mengamati hasil kuesioner. Deskriptif jawaban responden digunakan untuk menganalisis data berdasarkan hasil jawaban responden terhadap masing-masing indikator pengukur variabel.

Tabel 1 Statistik Deskriptif

\begin{tabular}{|l|c|c|c|c|c|c|}
\hline \multirow{2}{*}{ Variabel } & \multirow{2}{*}{ N } & \multicolumn{2}{c|}{ Teoritis } & \multicolumn{3}{c|}{ Aktual } \\
\cline { 3 - 7 } & & Kisaran & Mean & Kisaran & Mean & $\begin{array}{c}\text { Std. } \\
\text { Deviasi }\end{array}$ \\
\hline Akuntabilitas & 215 & $5-25$ & 15 & $11-25$ & 18,33 & 2,631 \\
\hline Responsibilits & 215 & $5-25$ & 15 & $13-25$ & 18,98 & 2,295 \\
\hline Transparansi & 215 & $5-25$ & 15 & $10-25$ & 18,29 & 2,621 \\
\hline Independensi & 215 & $5-25$ & 15 & $14-25$ & 19,14 & 2,057 \\
\hline Keadilan & 215 & $4-20$ & 12 & $9-20$ & 14,86 & 2,158 \\
\hline $\begin{array}{l}\text { Syariah } \\
\text { Corpliance }\end{array}$ & 215 & $5-25$ & 15 & $15-25$ & 19,13 & 2,521 \\
\hline Repuasan & 215 & $5-25$ & 15 & $10-25$ & 18,02 & 2,606 \\
\hline $\begin{array}{l}\text { Loyalitas } \\
\text { Muzakiki }\end{array}$ & 215 & $6-30$ & 18 & $12-30$ & 21,37 & 3,293 \\
\hline
\end{tabular}

Hasil uji statistik deskriptif menunjukkan bahwa bahwa masing-masing variabel memiliki mean aktual>mean teoritis, sehingga dapat dikatakan bahwa rata-rata penerapan prinsip syariah governance yang diterapkan oleh Lembaga Amil Zakat tinggi terhadap kepuasan dan loyalitas muzakki.

Hasil Uji Validitas dan Reliabilitas

Analisis konfirmatori atau Confirmatory Factor Analysis (CFA) digunakan untuk menguji suatu konstruk teoritis (Ghozali, 2014). Sebelum melakukan pengujian hipotesis, perlu dilakukan analisis konfirmatori eksogen yang bertujuan untuk menguji apakah seluruh indikator valid terhadap variabel latennya. Hasil uji konfirmatori faktor, menunjukkan bahwa semua indikator memiliki nilai loading factor di atas 0,5 dan bernilai positif. Dengan demikian butir pertanyaan tersebut dinyatakan valid. Sehingga semua item pertanyaan memenuhi syarat atau dapat digunakan untuk penelitian selanjutnya dan mampu mewakili variabel yang diteliti.

Reliabilitas merupakan konsistensi dari pengukuran suatu model. Variabel konstruk mempunyai tingkat reliabilitas yang tinggi apabila nilai Construct reliability $(\mathrm{Cr}) \geq 0,70$. Berdasarkan Tabel 1 diketahui bahwa semua variabel yang digunakan memiliki Construct reliability $(\mathrm{Cr}) \geq 0,70$ sehingga dapat dikatakan bahwa setiap variabel yang digunakan dalam penelitian ini reliabel.

Tabel 2 Hasil Uji Reliabilitas

\begin{tabular}{ll}
\hline Variabel & Reliabilitas \\
\hline Akuntabilitas & 0,782 \\
Responsibilitas & 0,759 \\
Transparansi & 0,813 \\
Independensi & 0,779 \\
Keadilan & 0,804 \\
Syariah Compliance & 0,835 \\
Kepuasan & 0,835 \\
Loyalitas & 0,846 \\
\hline
\end{tabular}


Hasil Uji Model Struktural

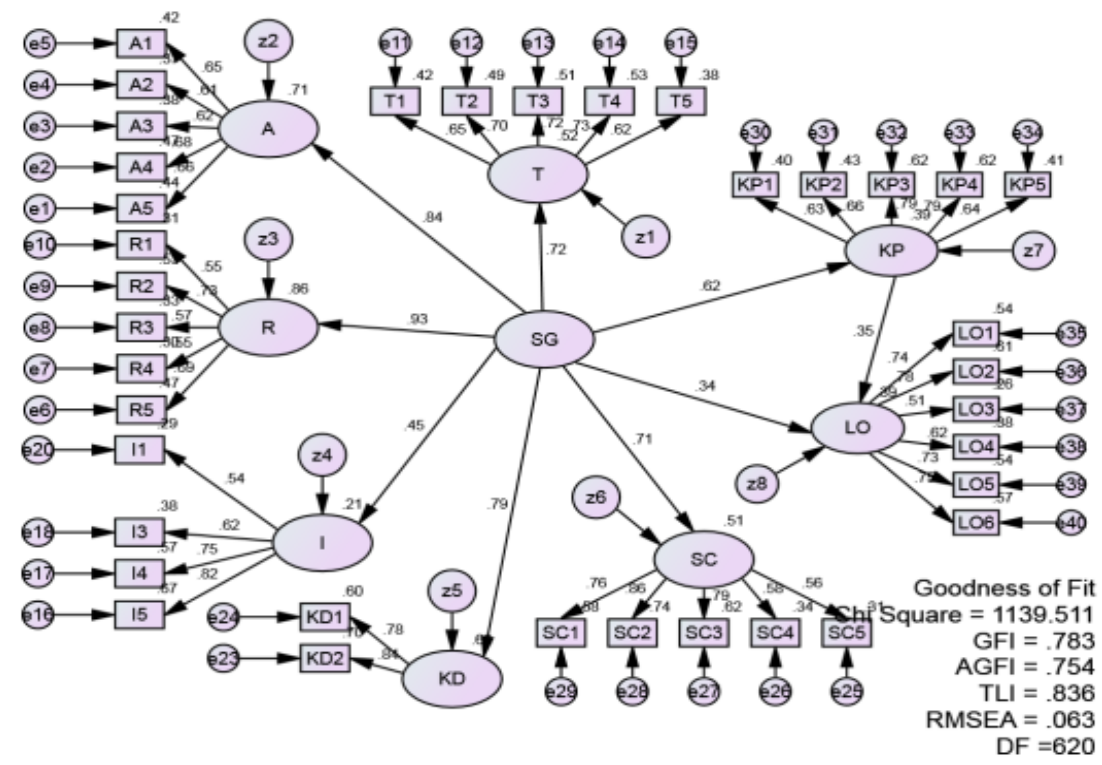

Gambar 2 Model Struktural

Sumber: Data Primer diolah tahun 2018, AMOS 22.0

Tabel 3 Goodness of Fit: Model Struktural

\begin{tabular}{|c|c|c|c|}
\hline GoFInder & Cut off & Nilai Peuelitian & Keterangan \\
\hline GI & $\$ 0$ & 0,783 & Tidak Fit \\
\hline AGI & S0 & 0,754 & Tidak Fit \\
\hline ILI & 90 & 0,836 & Margnal \\
\hline RMSA & 2008 & 0,063 & Fit \\
\hline
\end{tabular}

Surber: Data Prime sudah diolah tahun 2018, ANOS220

Gambar dan tabel menunjukkan bahwa model tersebut belum fit maka tahap selanjutnya adalah melakukan uji asumsi klasik agar di dapatkan model yang lebih fit. Uji asumsi klasik terdiri dari uji outlier, uji normalitas, dan multikolinearitas.

Evaluasi Outlier

Kriteria yang digunakan bila terdapat data yang nilainya $<0,05$ yang terletak pada $\mathrm{p} 1$ dan $\mathrm{p} 2$ maka data tersebut sebaiknya dihapus secara bertahap. Evaluasi outlier dilakukan untuk menghasilkan normalitas data yang diharapkan. Dari 215 data yang terkumpul, tersisa 156 data yang dapat diolah.

Uji Normalitas

SEM mensyaratkan suatu data harus berdistribusi normal secara univariate maupun multivariate. Evaluasi normalitas data yaitu dengan kriteria critical ratio skewness value semua indikator menunjukkan distribusi normal karena nilainya $<2,58$ dan untuk uji normalitas multivariate data di atas memberikan nilai cr 2,568<2,58. Jadi dapat disimpulkan secara multivariate berdistribusi normal. 
Uji Multikolinearitas

Salah satu asumsi yang harus terpenuhi di dalam analisis multivariate adalah multikolinearitas. Asumsi multikolinearitas akan memberikan justifikasi bahwa tidak ada korelasi sempurna di antara variabel independen. Nilai korelasi antara variabel independen yang tidak diperbolehkan adalah $\geq 0,9$ (Santoso, 2015). Hasil pengujian multikolinearitas pada penelitian ini tidak ada nilai kolerasi di atas 0,9, sehingga dapat disimpulkan bahwa seluruh variabel independen tidak memiliki korelasi sempurna. Dengan demikian data ini telah memenuhi asumsi multikolinearitas, sehingga data penelitian ini dapat digunakan untuk tahap pengolahan data dengan SEM.

Hasil Pengujian Hipotesis

Ringkasan dari hasil uji hipotesis dengan evaluasi nilai parameter model struktural untuk mengetahui pengaruh syariah governance terhadap kepuasan dan loyalitas muzakki ditunjukkan pada Tabel 4 .

Tabel 4 Uji Hipotesis

\begin{tabular}{|c|c|c|c|}
\hline \multicolumn{1}{|c|}{ Hipoteris } & Estimate & Siguifikausi & Keteraugau \\
\hline $\begin{array}{l}\text { Syariah Govemance } \\
\text { - Kepuasin }\end{array}$ & 0,323 & 0,000 & $\begin{array}{c}\text { Hipotesis } \\
\text { Diterima }\end{array}$ \\
\hline $\begin{array}{l}\text { Syariah Govemanca } \\
\text { - Loyalita Muzaki }\end{array}$ & 0,349 & 0,000 & $\begin{array}{c}\text { Hipotesis } \\
\text { Diterima }\end{array}$ \\
\hline $\begin{array}{l}\text { Kepuasan } \rightarrow \text { Loyalitas } \\
\text { Muzaki }\end{array}$ & 0,184 & 0,265 & $\begin{array}{c}\text { Hipotesis } \\
\text { Ditolak }\end{array}$ \\
\hline
\end{tabular}

Uji Hipotesis 1

Lembaga Amil Zakat merupakan suatu lembaga yang bertugas untuk menghimpun, mengelola, dan menyalurkan zakat. Lembaga Amil Zakat bergerak di bidang kemanusiaan dan sosial, sehingga LAZ selalu berupaya untuk mengutamakan kepentingan umat. Untuk memenuhi kepentingan umat, LAZ menjalankan kegiatannya dengan jujur, amanah, tanggungjawab, dan sesuai dengan prinsip syariah. Hal tersebut sesuai dengan prinsip-prinsip syariah governance.

Apabila LAZ menerapkan prinsip-prinsip syariah governance di dalam setiap kegiatannya, maka LAZ akan berupaya untuk memberikan pelayanan yang terbaik dan sesuai dengan syariat Islam, dengan demikian LAZ akan memperoleh kepercayaan dari muzakki. Hal tersebut didukung oleh teori Stewardship, yang mana di dalam teori tersebut disebutkan bahwa manajemen dapat dipercaya apabila manajemen bekerja dengan baik untuk kepentingan publik (Kaihatu, 2006). Timbulnya rasa percaya muzakki terhadap Lembaga Amil Zakat, disebabkan karena adanya rasa puas dan yakin atas layanan yang diberikan oleh lembaga tersebut. Ketercapaian kepuasan muzakki terjadi apabila pemenuhan pelayanan sesuai dengan harapan muzakki. Kepuasan muzakki merupakan respon yang diberikan muzakki terhadap Lembaga Amil Zakat atas kesesuaian kepentingan dan kinerja aktual dari lembaga tersebut. Sejalan dengan penelitian Firmansyah dan Devi (2017), yang menyebutkan bahwa untuk meningkatkan potensi zakat di Indonesia maka diperlukan adanya prinsip-prinsip good shariah governance pada Lembaga Amil Zakat untuk meningkatkan kepuasan dalam pembayaran zakat.

Hasil pengujian (H1) menunjukkan bahwa Syariah Governance berpengaruh positif signifikan terhadap Kepuasan. Berdasarkan hasil perhitungan yang telah diperoleh melalui regression weight pada nilai probabilitas dengan taraf signifikansi sebesar 0,000 lebih kecil dari 0,05 
dan arah hipotesis menunjukkan positif dilihat dari nilai standardized sebesar 0,323 dengan demikian hipotesis diterima. Pengujian ini secara statistik membuktikan variabel syariah governance berpengaruh positif signifikan terhadap kepuasan muzakki. Dengan demikian, semakin tinggi penerapan syariah governance di dalam LAZ, maka akan semakin tinggi pula kepuasan yang didapatkan oleh muzakki.

\section{Uji Hipotesis 2}

Lembaga Amil Zakat merupakan suatu lembaga yang beroperasi untuk memberikan manfaat bagi seluruh umat manusia khususnya umat muslim. LAZ menjaga kepercayaan masyarakat dan memenuhi kepentingan umat dengan menerapkan prinsip syariah governance di dalam setiap kegiatannya. Dengan demikian, LAZ menjalankan seluruh kegiatannya dengan jujur, amanah, adil, terbuka, sesuai dengan syariah, dan selalu memberikan informasi mengenai seluruh kegiatan lembaga zakat yang dapat mempengaruhi pengambilan keputusan dari para muzakki. Dengan menerapkan prinsip syariah governance dan memberikan layanan yang baik serta terpercaya, maka masyarakat dapat menilai bahwa lembaga zakat tersebut dapat menghimpun, mengelola, dan menyalurkan dana ZIS dengan baik dan tepat sasaran sehingga akan mempengaruhi keputusan muzakki untuk menyalurkan dana ZIS melalui lembaga tersebut.

Hal itu didukung oleh teori stakeholder yang menyatakan bahwa stakeholder sebagai pengambil keputusan muslim mengharapkan Lembaga Amil Zakat mengungkapkan pertanggungjawabannya untuk memenuhi konsep syariah governance yang sesuai dengan syariah Islam, sehingga dapat membuktikan bahwa Lembaga Amil Zakat beroperasi sesuai dengan prinsip kepatuhan syariah. Hasil implikasi dari pertanggungjawaban Lembaga Amil Zakat diharapkan dapat memudahkan muzakki untuk mengambil segala keputusan yang berkaitan dengan pembayaran dana zakat, infak, dan sedekah (ZIS) melalui Lembaga Amil Zakat.

Pertanggungjawaban yang diberikan oleh LAZ yang diwujudkan dengan menerapkan prinsip syariah governance secaea terus-menerus akan mempengaruhi citra LAZ dan mempengaruhi pandangan muzakki terhadap LAZ sehingga apabila muzakki memiliki pandangan yang baik terhadap LAZ dalam jangka waktu yang panjang, maka akan tercipta suatu loyalitas muzakki dalam menyalurkan zakatnya melalui lembaga tersebut (Sutomo dkk, 2017). Hal ini didukung oleh teori persepsi, yang mana suatu tindakan atau kejadian dapat mempengaruhi persepsi seseorang. Persepsi diartikan sebagai suatu proses berupa tanggapan yang diberikan oleh seseorang berdasarkan cara pandang dan pola pikirnya terhadap suatu kejadian tersebut. Loyalitas merupakan tanggapan dari muzakki, yang mana muzakki telah memiliki sudut pandang dan pola pikir tersendiri atas kualitas layanan dan citra dari Lembaga Amil Zakat tersebut. Hal ini didukung beberapa penelitian Umam (2011) yang menyatakan bahwa good corporate governance berpengaruh terhadap loyalitas nasabah. Penelitian Jumaizi, dkk (2011) juga menyebutkan bahwa prinsip-prinsip good corporate governance mempunyai pengaruh yang positif dan signifikan terhadap kepuasan serta loyalitas muzakki.

Hasil pengujian (H2) menunjukkan bahwa syariah governance berpengaruh positif dan signifikan terhadap loyalitas muzakki. Berdasarkan hasil perhitungan yang telah diperoleh melalui regression weight pada nilai probabilitas dengan taraf signifikansi sebesar 0,000 lebih kecil dari 0,05 dan arah hipotesis menunjukkan positif dilihat dari nilai standardized sebesar 0,349 dengan demikian hipotesis diterima. Pengujian ini secara statistik membuktikan variabel syariah governance berpengaruh positif dan signifikan terhadap loyalitas muzakki. Dengan demikian dapat disimpulkan bahwa semakin tinggi penerapan syariah governance di dalam LAZ, maka akan semakin tinggi pula loyalitas muzakki dalam menyalurkan zakatnya melalui LAZ.

\section{Uji Hipotesis 3}

Muzakki dapat merasakan perasaan puas ketika segala pemenuhan kebutuhannya dapat terpenuhi. LAZ diharapkan dapat memberikan pelayanan yang berkualitas agar muzakki mendapatkan kepuasan sehingga meningkatkan loyalitasnya dalam menyalurkan dana zakat. 
Kepuasan sendiri lebih diartikan dengan perilaku manusia yang merasa mendapatkan suatu kebutuhan yang sesuai dengan harapannya bahkan hasilnya bisa lebih dari yang dibutuhkan. Apabila muzakki merasa puas terhadap LAZ, maka muzakki akan cenderung membayarkan zakatnya secara berulang melalui lembaga dan bila hal tersebut dirasa benar-benar dapat diyakini untuk dilakukan dalam waktu yang lama maka akan timbul loyalitas terhadap lembaga tersebut.

Menurut Ishak dan Luthfi, (2011), loyalitas pelanggan terbentuk dari kepuasan pelanggan jangka panjang. Kepuasan muzakki juga merupakan salah satu hal yang penting bagi lembaga amil zakat. Ketika muzakki merasa puas terhadap pelayanan yang diberikan oleh Lembaga Amil Zakat maka muzakki akan cenderung untuk kembali membayarkan zakatnya pada lembaga amil zakat tersebut, yang mana hal ini adalah indikator yang menyebabkan timbulnya loyalitas muzakki.

Hal ini sejalan dengan penelitian Yuliafitri dan Khoiriyah (2016) yang membuktikan adanya pengaruh yang positif dan signifikan antara kepuasan dengan loyalitas muzakki. Semakin tinggi tingkat kepuasan muzakki maka akan semakin tinggi pula tingkat loyalitasnya. Akan tetapi di dalam penelitian ini menyatakan bahwa kepuasan tidak berpengaruh terhadap loyalitas muzakki.

Hasil pengujian (H3) menunjukkan bahwa kepuasan tidak berpengaruh terhadap loyalitas muzakki. Berdasarkan hasil perhitungan yang telah diperoleh melalui regression weight pada nilai probabilitas dengan taraf signifikansi sebesar 0,265 lebih besar dari 0,05 (tidak signifikan) dan arah hipotesis menunjukkan positif dilihat dari nilai standardized sebesar 0,184 dengan demikian hipotesis ditolak. Pengujian ini secara statistik membuktikan variabel kepuasan tidak berpengaruh signifikan terhadap loyalitas muzakki.

Hal ini diduga karena adanya sensitivitas keagamaan yang tinggi, sehingga meskipun muzakki tidak merasa puas dengan layanan yang diberikan oleh Lembaga Amil Zakat, tetapi muzakki tetap membayarkan zakatnya melalui lembaga tersebut. Begitu pula sebaliknya, LAZ mungkin sudah memberikan pelayanan yang baik dan muzakki sudah merasa puas tetapi muzakki merasa dapat menyalurkan zakatnya secara langsung tanpa melalui Lembaga Amil Zakat. Selain itu dapat juga disebabkan karena adanya kebiasaan atau pengaruh persepsi dari keluarga, sehingga mungkin muzakki belum merasa puas dengan layanan yang diberikan oleh LAZ, tetapi karena keluarganya mayoritas atau sudah menjadi kebiasaan dari keluarganya untuk membayarkan zakat melalui lembaga tersebut, maka muzakki tersebut akan tetap menyalurkan zakatnya melalui LAZ walaupun pelayanan yang diberikan oleh LAZ masih belum maksimal.

\section{KESIMPULAN}

Berdasarkan uji hipotesis dengan evaluasi nilai parameter model struktural, ditemukan hasil bahwa: pertama, syariah governance berpengaruh positif signifikan terhadap kepuasan. Kedua, syariah governance berpengaruh signifikan terhadap loyalitas muzakki. Ketiga, kepuasan tidak berpengaruh signifikan terhadap loyalitas muzakki.

Penelitian ini terdapat keterbatasan penelitian yakni penelitian ini hanya terbatas pada Lembaga Amil Zakat yang ada di Daerah Istimewa Yogyakarta. Selain itu, penelitian ini membutuhkan waktu yang cukup lama dalam pengumpulan data penelitian. Oleh karenanya penelitian selanjutnya diharapkan lebih memperluas jangkauan penelitian dengan memperluas cakupan Lembaga Amil Zakat sehingga tidak hanya terfokus pada wilayah Daerah Istimewa Yogyakarta dan mendapatkan hasil yang lebih komprehensif. Selain itu penelitian selanjutnya agar menambah variabel penelitian dan memperluas sample penelitian agar lebih dapat di generalisasikan. 


\section{DAFTAR PUSTAKA}

Adnan, B. (2018). Analisis Hubungan Kualitas Pelayanan Lembaga Amil Zakat dengan Kepuasan Muzakki dan Pengaruhnya Terhadap Loyalitas Muzakki. Skripsi Universitas Islam Negeri Jakarta.

Adnan, M. A. (2017). The Need of Establishment of Professional Amil Zakat to Enhance the Future Zakat Development. International Journal of Zakat, 2(1), 71-79.

Adnan, M. A., \& Abu Bakar, N. B. (2009). Accounting Treatment for Corporate Zakat: a Critical Review. International Journal of Islamic and Middle Eastern Finance and Management, 2(1).

Agustiyanti. (2018). Utang Luar Negeri RI Hingga November 2017. Diakses dari: https://www.cnnindonesia.com/ekonomi/20180116110410-532-269209/utang-luar-negeri-rihingga-november-2017-rp4562-triliun. Diakses pada tanggal 19 April 2018 pukul 20:31.

Arbaina, E. S. (2012). Penerapan Good Corporate Governance Pada Perbankan di Indonesia. Jurnal Akuntansi Universitas Negeri Surabaya 1(1).

Assaggaf, M. A. (2016). Pengaruh Akuntabilitas dan Transparansi Pengelolaan Zakat Terhadap Minat Muzakki Membayar Zakat (Studi Pada BAZNAS Kota Makassar Ruang Lingkup UPZ Kantor Kementerian Agama Kota Makassar). Thesis Universitas Islam Negeri Alauddin Makassar.

Aviyatisari, Radita. (2016). Pengaruh Implementasi Syariah Governance dan Kepuasan Terhadap Loyalitas Nasabah (Studi Empiris Pada Perbankan di Yogyakarta). Skripsi Universitas Muhammadiyah Yogyakarta.

Badan Pusat Statistika Daerah Istimewa Yogyakarta. 2018. Profil Kemiskinan Daerah Istimewa Yogyakarta 2018. Diakses dari: https://yogyakarta.bps.go.id/pressrelease/2018/07/16/891/profil-kemiskinan daerahistimewa-yogyakarta-maret-2018. Diakses pada tanggal 11 November 2018 pukul 21:04.

Badan Pusat Statistika. 2011. Kewarganegaraan, Suku Bangsa, Agama, dan Bahasa Sehari-hari Penduduk Indonesia Hasil Sensus Penduduk 2010.

BAZNAS dan Fakultas Ekonomi dan Manajemen IPB. (2011). Estimasi Potensi Zakat Nasional. Majalah SABILI No.24/XVIII.

BAZNAS. (2016). Statistika Penghimpunan ZIS. Outlook Zakat Indonesia Tahun 2016.

Chariri \& Ghozali, I. (2007). Teori Akuntansi. Semarang: Badan Penerbit Universitas Diponegoro.

Choiriyyah, S. (2016). Pengaruh Implementasi Syariah Governance Terhadap Loyalitas Muzakki (Studi Empiris pada Lembaga Amil Zakat di Yogyakarta). Skripsi Universitas Muhammadiyah Yogyakarta.

Deegan, C. (2004). Financial Accounting Theory. Sydney: McGraw-Hill Book Company.

Deegan, C., et al. (2002). An Examination of The Corporate Social Environmental Disclosures of BHP from 1983-1997: A Test of Legitimacy Theory. Accounting, Auditing, and Accountability Journal, 15(3), 312-343.

Departemen Agama RI. (2010). Fiqih Zakat. Direktorat Pembedayaan zakat. Direktorat Jendral Bimbingan Masyarakat Islam.

Donaldson, L., \& Davis, J.H. (1991). Stewardship Theory or Agency Theory: CEO Governance and Shareholder Returns. Australian Journal of Management, 16(1), 49-65.

Dowling, J., \& Pfeffer, J. (1975). Organizational Legitimacy: Social Values and Organizational Behavior. Pacific Sociological Journal Review, 18, 122-136.

Ferdinand, A. (2002). Structural Equation Modelling dalam Penelitian Manajemen. Semarang: Undip.

Firdaus, Beik, Irawan, \& Juanda. (2012). Economic Estimation and Determinations of Zakat Potensial in Indonesia. IRTI Working Paper Series.

Firmansyah, I., \& Devi, A. (2017). The Implementation Strategies of Good Corporate Governance for Zakat Institutions in Indonesia. International Journal of Zakat, 2 (2), 85-97. 
Ghozali, I. (2014). Konsep dan Aplikasi dengan Program AMOS 22.0 Update Bayesian SEM. Semarang: BP UNDIP.

Griffin, J. (2003). Customer Loyalty: How to Keep it, how to earn it. New York: Lexington books.

Gunawan, K. (2017). Pelayanan Lembaga Zakat Untuk Meningkatkan Kepuasan Muzakki. Jurnal Zakat dan Wakaf, 4(2).

Hafidhuddin, D. (2002). Zakat dalam Perekonomian Modern. Jakarta: Gema Insani. hlm. 93123.

Hakim, L. (2017). Pengelolaan Zakat di DIY Belum Optimal. Diakses dari: https://www.antaranews.com/berita/649861/kemenag-pengelolaan-zakat-di-div-belumoptimal. Diakses pada 20 April 2018 pukul 22:25.

Hayati, N. (2017). Transparansi Informasi dan Kepuasan Terhadap Loyalitas Muzakki (Studi pada Muzakki di LAZIS UNS). Skripsi Universitas Negeri Sebelas Maret.

Ishak, A., \& Luthfi, Z. (2011). Pengaruh Kepuasan dan Kepercayaan Konsumen Terhadap Loyalitas: Studi Tentang Peran Mediasi Switching Costs. Jurnal Siasat Bisnis, 15(1).

Jogiyanto. (2014). Pedoman Survei Kuesioner. BPFE-YOGYAKARTA.

Jumaizi, S. dkk. (2011). Good Governance Badan Amil Zakat, Infak, dan Sedekah Dan Dampaknya Terhadap Keputusan dan Loyalitas Muzakki. Majalah Ilmiah Informatika, 2(3).

Junusi, R. E. (2012). Implementasi Syariah Governance Serta Implikasinya Terhadap Reputasi Dan Kepercayaan Bank Syariah. Annual International Conference on Islamic Studies (AICIS) 12 Tahun 2013, 5-8 Nopember 2013, Surabaya.

Kaihatu, T. S. (2006). Good Corporate Governance dan Penerapannya di Indonesia. Jurnal Manajemen dan Kewirausahaan, 8(1), 1-9.

Kementerian Agama. (2012). Laporan Tahunan Kehidupan Keagamaan di Indonesia 2012. Jakarta: Badan Litbang dan Diklat Puslitbang Kehidupan Keagamaan.

Kotler, P., \& Keller, K. L. (2009). Manajemen Pemasaran. Jakarta: Penerbit Erlangga.

Kuncaraningsih, H. S., \& Ridla, M. R. (2015). Pengaruh Good Coporate Governance Terhadap Kepuasan Muzakki Pada Badan Amil Zakat Nasional (BAZNAS) Kabupaten Sleman Yogyakarta. Jurnal Membangun Profesionalisme Keilmuan.

Laucereno, S. F. (2018). Data Kemiskinan RI 5 Tahun Terakhir Menurut BPS.diakses dari: https://finance.detik.com/berita-ekonomi-bisnis/d-4138150/ini-data-kemiskinan-ri-5-tahunterakhir-menurut-bps. Diakses pada tanggal 11 November 2018 pukul 21:21.

Mahardika, W. R. (2018). Faktor-faktor Eksternal yang Mempengaruhi Muzakki Menyalurkan Zakat, Infaq, dan Shodaqoh Melalui Lembaga Amil Zakat SoloPeduli. Thesis Universitas Muhammadiyah Surakarta.

Mustika, K. S. 2018. Potensi Zakat DIY Capai 150 Miliar. Diakses dari: https://m.harianjogja.com/jogjapolitan/read/2018/06/06/510/920519/potensi-zakat-diycapai-150-miliar. Diakses pada tanggal 11 November 2018 pukul 21:06.

Nazaruddin, I \& Basuki, A. T. (2015). Analisis Statistik dengan SPSS. Yogyakarta: Danisa Media.

Nurhayati, S. (2015). Akuntansi Syariah di Indonesia. Jakarta: Salemba Empat.

PSAK 109 tentang Akuntansi Zakat dan Infak/Sedekah.

Purnamasari, I., \& Darma, E. S. (2015). Pengaruh Implementasi Syariah Governance Terhadap Loyalitas Nasabah (Studi Empiris pada Perbankan Syariah di Yogyakarta). Universitas Muhammadiyah Yogyakarta. Journal of Accounting and Investment, 16(1).

QS. Al-Baqarah ayat 110 tentang Perintah untuk Menunaikan Zakat bagi Umat Muslim.

QS. At-Taubah ayat 60 tentang Golongan yang Berhak Menerima Zakat (Mustahiq).

Santoso, S. (2015). AMOS 22 untuk Structural Equation Modelling. Jakarta: PT Elex Media Komputindo.

Sasongko, A. (2017). Zakat dan Potensinya untuk Indonesia di 2017. Dikases dari: https://www.republika.co.id/berita/duniaislam/wakaf/17/12/26/p1kkxs313-zakat-danpotensinya-untuk-indonesia-di-2017. Diakses pada 22 April 2018 pukul 20:12. 
Setiawan, F. (2017). Pengaruh Religiusitas, Kepercayaan dan Reputasi Terhadap Minat Muzakki dalam Membayar Zakat Profesi (Studi Kasus di Kabupaten Ponorogo). Thesis Program Studi Magister Manajemen. Universitas Muhammadiyah Surakarta.

Sugihartono, dkk. (2007). Psikologi Pendidikan. Yogyakarta: UNY Press.

Sugiyono. (2010). Metode Penelitian Bisnis, cetakan 15, Bandung: Alfabeta.

Sutomo, dkk., (2017). Pengaruh Kualitas Pelayanan Lembaga Amil Zakat (LAZ) Terhadap Kepuasan dan Loyalitas Muzakki (Studi Kasus LAZ PKPU Yogyakarta). Jurnal Aplikasi Bisnis dan Manajemen, 3 (1).

Umam, M. (2011). Pengaruh Penerapan Good Corporate Governance Terhadap Loyalitas Nasabah (Studi pada BPRS Artha Mas Abadi Pati). Skripsi Fakultas Syari'ah Institut Agama Islam Negeri Walisongo. Semarang.

Undang-undang No. 23 Tahun 2011 tentang Pengelolaan Zakat.

Walgito, B. (2004). Pengantar Psikologi Umum. Jakarta: Andi Offset.

Wantara, P. (2015). The Relationships among Service Quality, Customer Satisfaction, and Customer Loyalty in Library Services. International Journal of Economics and Financial Issues, 5 (Special Issue) 264-269.

Wardayati, S. (2011). Implikasi Shariah Governance Terhadap Reputasi dan Kepercayaan Bank Syariah. Jurnal Walisongo, 19(1).

Windriatmoko, R. A. (2016). Analisis Pengaruh Pelayanan Terhadap Tingkat Kepuasan dan Loyalitas Muzakki (Studi Kasus BAZNAS Kota Bogor). Skripsi Institut Pertanian Bogor.

Yuliafitri, I., \& Khoiriyah, A. N. (2016). Pengaruh Kepuasan Muzakki, Transparansi dan Akuntabilitas Pada Lambaga Amil Zakat Terhadap Loyalitas Muzakki (Studi Persepsi Pada LAZ Rumah Zakat). Jurnal Ekonomi dan Islam. Volume, 7 (2). 